\title{
IS SOCIETY WILLING TO DONATE TO WAQF? OPINIONS OF THE STATE ISLAMIC RELIGIOUS COUNCILS IN MALAYSIA
}

\author{
Farhana Mohamad Suhaimi ${ }^{1}$ \\ Asmak Ab Rahman ${ }^{2}$
}

\begin{abstract}
This study aims to identify the awareness and understanding of Muslims in Malaysia regarding the development of waqf property. This research was conducted through interviews with selected State Islamic Religious Councils (MAINs) Waqf Department officers as they have vast experience in leading society towards waqf property management. In addition, a literature review was undertaken on contemporary studies dealing with this subject. The study found that awareness and understanding of Muslims regarding waqf property in Malaysia varies due to different approaches instituted by MAINs in their respective states.
\end{abstract}

Keywords: waqf, waqf awareness, waqf management, Malaysia, endowment

1 Ph.D Candidate, Department of Shariah and Economics, Academy of Islamic Studies, University of Malaya, 50603, Kuala Lumpur, Malaysia, anafarhana10@ gmail.com

2 Senior Lecturer, Department of Shariah and Economics, Academy of Islamic Studies, University of Malaya, 50603, Kuala Lumpur, Malaysia, asmak@um.edu. my 


\section{INTRODUCTION}

Humans need each other in order to achieve their goals. This is because people have different capabilities and talents. In conformity with the need for community, Islam teaches its followers that all of mankind are a brotherhood. On this basis, people are encouraged to help each other to make life more orderly and harmonious. As Allah SWT states in the al-Quran:

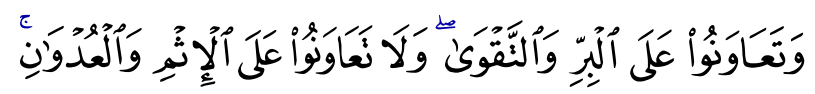

"Help you one another in al-birr and al-taqwa (virtue, righteousness, and piety); but do not help one another in sin and transgression..." 3

(Surah al-Mā'idah, 5: 2)

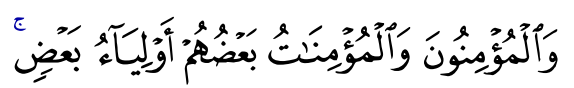

"The believers, men and women, are awliya (helpers, supporters, friends, protectors) of one another..." 4

(Surah al-Tawbah, 9: 71)

Therefore, each individual is responsible for not only meeting the needs of their own lives and family members, but also to promote the welfare of society as a whole. Along with zakāh, waqf is a mechanism for the redistribution of wealth which can help to ensure the socio-economic welfare of the community. There are a variety of facilities and services in a Muslim-majority society, such as mosques, schools, universities, libraries, research centers and agencies, rest homes, residential homes, public baths, soup kitchens, hospitals, water catchment projects, fountains, roads, bridges, shops, and workshops - all which have been funded from waqf sources. Thus, waqf institutions should be developed with the cooperation of every individual in society.

In this study, first an attempt will be made to examine waqf in a Muslim majority society - particularly Malaysia - and the functions of waqf on the country's development. Afterwards, there will be detailed discussion on waqf practices in Malaysia. Although, the practice of waqf has long been ingrained

3 Muhammad Taqi-ud-Din Al-Hilali \& Muhammad Muhsin Khan, Translation of the Meanings of the Noble Qur'an in the English Language (Madinah: King Fahd Complex for the Printing of the Holy Qur'an, 2000), 141.

4 Muhammad Taqi-ud-Din Al-Hilali \& Muhammad Muhsin Khan, Translation of the Meanings of the Noble Qur'an in the English Language, 256. 
in Malaysia, awareness and understanding among Malaysian Muslims are still limited. Thus, this study will identify said awareness and understanding of Malaysian Muslims regarding the development of waqf property in detail. The resulting analyses from this study analyses raises the challenges related to waqf understanding and the efforts which State Islamic Religious Councils (MAINs) have implemented in their respective regions. The study will contribute to waqf institutions, such as MAINs, to strategize their approach in order to encourage public participation in waqf development.

\section{WAQF IN SOCIETY}

The Prophet Muhammad (PBUH) was the first person to start an endowment when he contributed his own funds to the "Masjid Quba", which was built when he first arrived in Medina. He also endowed seven farms in Medina, which were given to him by Mukhairiq. ${ }^{5}$ The actions of the Prophet Muhammad (PBUH) are an example and a model for society. Moreover, the encouragement given to Muslims to perform righteous and good deeds are also expressed through the words of Allah SWT in the al-Quran:

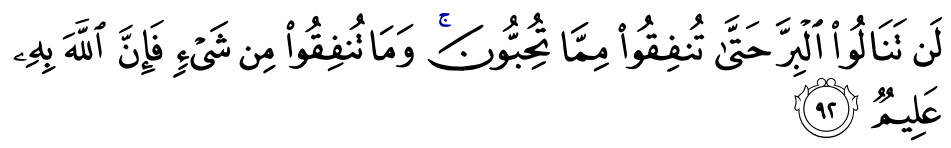

"By no means shall you attain Al-Birr (piety, righteousness - here it means Allah's Reward, i.e. Paradise), unless you spend (in Allah's Cause) of that which you love; and whatever of good you spend, Allah knows it well." ${ }_{6}$

(Surah Āli-'Imrān, 3: 92)

When Abu Talha - one of the Prophet's companions and also a very rich man in Medina - heard about this verse, he endowed his most favourite garden,

5 Monzer Kahf, 'Waqf and its Sociopolitical Aspects', www.iefpedia.com/english/ wp.../Waqf-and-its-Socio-Political-Aspects1.pdf, accessed 20 March 2014; Monzer Kahf, 'Waqf: A Quick Review', http://monzer.kahf.com/papers/english/ WAQF_A_QUICK_OVERVIEW.pdf, accessed 20 March 2014.

6 Muhammad Taqi-ud-Din Al-Hilali \& Muhammad Muhsin Khan, Translation of the Meanings of the Noble Qur'an in the English Language, 86. 
Bairuhā in Medina, for the purpose of welfare and Allah's blessings. ${ }^{7}$ In addition, Umar RA also endowed his land in Khaibar after hearing the Prophet Muhammad's (PBUH) recommendation. The Prophet (PBUH) did not advise Umar to leave his property to the state even though he (PBUH) was the head of state at that time. This advice indicates that the Prophet (PBUH) saw the importance of the role of waqf to public welfare. ${ }^{8}$

In the early history of Islam, Muslims showed a high level of morality when they implemented the fard kifäyah (collective obligations). Normally, an individual Muslim would use part of their own property for public welfare, which is perhps the easiest way to create a waqf. The property was used in order to perform some public welfare projects such as establishing a hospital, rest house, or educational center. ${ }^{9}$ Such practices continued until the waqf became one of the main sources of government revenue - especially during the golden age of the Ottoman Empire. Waqf was used not only to benefit the poor and needy, but also as a source of funding for other public welfare projects.

Given that the function and role of waqf has such a big impact on the country's development, it should be developed not only by the government, but in cooperation with society as a whole. An example of this is al-Azhar University in Egypt which was originally developed as a result of the cooperation between the government and civil society. After this, al-Azhar University managed to raise funds through waqf donations from the public. As a result, the university has been able to generate its own income and no longer needs to depend on the government. The university has turned itself into a well-respected institution, free of government intervention. ${ }^{10}$

7 Ibn Kathīr, Tafsīr Ibn Kathīr, vol. 1 (Mișr: Maktabah Zahrān), 382; al-Qurțubī, al-Jāmi ' li Aḥkām al-Qur'ān, vol. 2 (Beirūt: Dār al-Kutub al-'Ilmiyyah, 1993), 85-86; Mālik bin Anas, al-Mūwatța' (Beirūt: Bayt al-Afkār al-Dawliyyah, 2004), 596; Shams al-Dīn Muḥammad, Nihāyah al-Muhtāj Ilā Sharh al-Minhāj, vol. 5 (Miṣr: Maktabah Muștafa al-Bābī al-Ḥalābī, 1938), 355; al-Baijūrī, Ibrāhīm, Hāshiyah al-Sheīkh Ibrāhīm al-Baijūrī; Sharh 'Alā Matan al-Sheīkh Abī Shujā', vol. 2 (Beirūt: Dār al-Kutub al-'Ilmiyyah, 2004), 77-78; al-Khațīb al-Sharbīn̄i, Mughnī al-Muhtāj Ilā Ma 'rifah Ma 'ānī Alfāz al-Minhāj al-Tālibīn, vol. 2 (Beirūt: Dār al-Fikr, 1978), 376; al-Khațīb al-Sharbīn̄i, al-Iqnā' fì Hil al-Alfāz Abì Shujā ', vol. 2 (Beirūt: Dār al-Kutub al-'Ilmiyyah, 2004), 162.

8 Mohammad Nejatullah Siddiqi, Role of the State in the Economy an Islamic Perspective (Leicester, United Kingdom: The Islamic Foundation, 1996), 149.

9 Ziauddin Ahmad, 'Public Finance in Islam,' IMF Working Paper, No. 89/68, (1989): 1-54.

10 Ahmad Zaki Ibrahim, 'Institusi al-Azhar: Keunggulan Pengurusan Dana Wakaf dalam Sejarah Tamadun Islam,' (Paper presented in Waqf Seminar, Seminar Wakaf Melestarikan Hadharah Ummah, Putrajaya, 22 December 2009). 
Similarly, in Turkey, waqf institutions that were established by contributions from public society have helped the government to fund their own national development expenses. Thus, it has been proven that public participation can ensure the survival of a waqf institution. In addition, undue reliance upon the government to develop the waqf sector is not a solution. If the government was also burdened with the development of waqf, it would only add an existing burden on the government, which may be best exemplified in the contemporary financial crisis of Greece, which resulted in the country's eventual bankruptcy. ${ }^{11}$ Therefore, every member of society plays a role in ensuring public welfare. The efforts to meet the community's needs will also contribute to the state's sustainable development. These efforts should be initiated by all members of society, whether it is capable individuals or institutions such as Government Linked Companies (GLC); even the corporate sector and private sector can play a role. ${ }^{12}$

Through waqf, members of society, either individuals, families, corporations, or the private sector, have the opportunity to contribute to the development of the country. Active participation from society is possible since waqf contributions can be in various forms, whether in the form of movable property, such as cash and shares, or immovable property, such as land and buildings. There are also no limitations on waqf donations. In fact, the benefits of waqf assets must be maintained (except on certain factors) that make waqf as a special mechanism of wealth redistribution in the long term.

The privileges of waqf combine elements of savings and investments, and the benefit of waqf can be used continuously, but can remain, inflated, and further developed. Thus, the involvement of the community through the practice of waqf can elevate the waqf institutions in Malaysia. It is intended that waqf stands alone as an instrument of public funding that is not only able to provide facilities and services in developing spirituality, education, health, economic and social matters, but can also reduce the burden of government in

11 Utusan Online Arkib, 'Aktifkan Peranan Sektor Ketiga,' http://www. utusan.com.my/utusan/ekonomi/20120611/ek_01/aktifkan-peranan-sektorketiga\#ixzz2DaEO78IQ, accessed 29 November 2012.

12 Nik Mustapha Nik Hassan, 'Sumbangan Institusi Wakaf kepada Pembangunan Ekonomi,' in Konsep dan Pelaksanaan Wakaf di Malaysia, ed. Nik Mustapha Nik Hassan (Kuala Lumpur: Institut Kefahaman Islam Malaysia (IKIM), 1999), 1-16; Ahmad Zaki Ibrahim, 'Institusi al-Azhar: Keunggulan Pengurusan Dana Wakaf dalam Sejarah Tamadun Islam'; Nik Mustapha Nik Hassan, 'Program Wakaf Proaktif Galak Penyertaan Umat,' http://e-kiosk.ikim.gov.my/downloadarticle. asp?id=53, accessed 1 September 2013. 
development work and create an environment that is conducive to the welfare of society.

\section{WAQF IN MALAYSIA}

In Malaysia, the practice of waqf has long been ingrained in society. This is evidenced by the existence of several institutions built on endowed land, such as mosques, religious schools, and cemeteries. All MAINs have to be held accountable as sole trustees in their respective states in Malaysia by the existence of related acts and special waqf guidelines. The Federal Constitution also provides for matters related to waqf in the Ninth Schedule, List 2 (State List), wherein claims that the laws for individuals and their families of persons professing the religion of Islam including waqf are subject to the jurisdiction of the state government except the Federal Territory of Kuala Lumpur, Labuan, and Putrajaya. ${ }^{13}$

The government and waqf institutions have realized the impact that waqf has, and they have been working to restore its role in solving the problems of social welfare while developing the local economy. Examples of such efforts include informing the public about the status of waqf, its importance in Islam, and its socio-economic contributions to society. The government's commitment manifested into the establishment of the Department of Awqaf, Zakat and Hajj (JAWHAR) on 27 March 2004. This led to the establishment of the Waqf Foundation Malaysia (YWM) on 23 July 2008. In 2013, the Prime Minister of Malaysia announced the upgrade of YWM to Waqf Corporation. These institutions have been established to uphold the development of waqf property in Malaysia in relation to various commercial projects built on waqf land for the benefit of the people.

Coinciding with the mission of JAWHAR and YWM towards promoting awareness of the potentials of waqf to the community ${ }^{14}$ is the attempt to remove the perception of uruf or cultural practice that donated land can only be used to develope mosques, cemeteries, and orphanages. In addition, the Islamic Development Bank (IDB), in its efforts to develop the potential of waqf, established the Awqaf Properties Investment Fund (APIF) in 2001. The establishment of this fund also stressed the importance to promote and develop

\footnotetext{
13 Senarai 2, Senarai Negeri, Jadual Kesembilan, Federal Constitution.

14 Yayasan Waqaf Malaysia, https://www.ywm.gov.my/profile/visi, accessed 20 March 2014.
} 
waqf property throughout the world and raise awareness among Muslims about the importance of waqf. ${ }^{15}$

\section{MALAYSIAN SOCIETY AND WAQF}

Research related to the awareness and understanding of waqf in Malaysia mostly tackles the subject indirectly. Normally, these discussions focus on the challenges and ways to conduct a program or any form of promotion that can increase public awareness and understanding related to waqf, especially reagarding the development of various contemporary waqf.

Latiff et al. explain that although in Malaysia people are generally aware about waqf and its role in society, understanding of it is still limited. ${ }^{16}$ People mostly prefer to donate their immovable property as a special type of waqf. Most of them believe that waqf is only limited to land, mosques, houses, buildings, and cemeteries. ${ }^{17}$ Siti Mashitoh Mahamood et al. states that there are still some communities that do not understand the concept of modern waqf - that is cash waqf schemes and waqf shares - and still question their permissibility. For example, the Islamic Religious Council of Penang (MAINPP) has to use the name 'waqf fund' in place of 'waqf share' to avoid confusion among the public. ${ }^{18}$

Understanding the beneficiary, heir(s) of waqf, and the local community are important. As explained by Mahamood et al., a narrow understanding by people can threaten the legal principles of Islamic endowment and ultimately interrupt the development of waqf. ${ }^{19}$ They also found that a limited understanding by

15 Abdul Halim Ramli, \& Kamarulzaman Sulaiman, 'Pembangunan Harta Wakaf: Pengalaman Negara-Negara Islam,' (Paper presented in Konvensyen Wakaf Kebangsaan, Kuala Lumpur, 12-14 September 2006).

16 Ahmad Zaki Abd Latiff, 'Pengurusan Harta Wakaf di Malaysia: Realiti \& Prospek,' (Paper presented in Islamic Real Estate Education: A New Paradigm, UiTM Shah Alam, Selangor, November 2011); Nik Mohd Zain Mohd Yusof \& Azimuddin Bahari, 'Kedudukan dan Potensi Pembangunan Hartanah Wakaf di Malaysia: Satu Penilaian,' in Konsep dan Pelaksanaan Wakaf di Malaysia, ed. Nik Hassan, N. M. (Kuala Lumpur: Institut Kefahaman Islam Malaysia (IKIM), 1999), 106-154.

17 Ahmad Zaki Abd Latiff, 'Pengurusan Harta Wakaf di Malaysia: Realiti \& Prospek.'

18 Siti Mashitoh Mahamood et al., 'Konsep dan Aplikasi Produk Wakaf Kontemporari di Malaysia: Saham Wakaf dan Wakaf Saham,' (Paper presented at the Seminar Ekonomi Islam Peringkat Kebangsaan 2009 (SEIPK '09), University of Malaya, Kuala Lumpur, 2009).

19 Siti Mashitoh Mahamood, 'Undang-Undang Pentadbiran Harta Wakaf,' (Paper presented at Seminar Penyelidikan Jangka Pendek (Vote F), University of Malaya, Kuala Lumpur, 11-12 Mac 2003). 
people can cause others to be less confident about the potentials of waqf in community development. ${ }^{20}$ Mohd also notes that this limited understanding creates a negative perspective for the community about the development of waqf projects. This is because waqf developments today focus on the economic side, such as the development of a 'waqf hotel', which is seem by many as a sinful decision. In reality, the construction of the hotel in question coincides with fardh kifayah so that Muslims can meet the needs of travelling people and for recreation. The hotel management was also charged with ensuring that management practices comply with th Shar'iah. ${ }^{21}$ In addition, a study conducted by Zain and Azimuddin found that negative perceptions about waqf development projects came from people who lived on waqf land. Thus, this was the sentiment of the residents themselves who wanted to protect their own interests on waqf land. ${ }^{22}$

Neighboring countries are also facing the same situation related to the awareness and understanding of the contemporary changes in managing and developing waqf. For example, Ramli and Sulaiman found that in Indonesia, the process of implementing the cash waqf through the Indonesia Waqf Fund (TWI) was hindered due to the limited understanding that Indonesians had about cash waqf. Collections records indicate that cash waqf made up Rp 100 million while the goal was Rp 2 billion. Therefore, TWI launched a marketing campaign in an attempt to make it separate from the zakat department. ${ }^{23}$ The media contributed to this discussion by stating that Act No. 41 of 2004 on waqf can encourage a change in the way Muslims think about waqf in Indonesia. ${ }^{24}$ Meanwhile in Patani, most Muslims are less aware of both waqf and cultural waqfs, and their potential. Waqf is still associated with unmovable assets such as land, houses, and buildings. In fact, the practice of waqf taught in Islam

20 Siti Mashitoh Mahamood et al., 'Konsep dan Aplikasi Produk Wakaf Kontemporari di Malaysia: Saham Wakaf dan Wakaf Saham.'

21 Anan C. Mohd, 'Pembangunan Tanah Wakaf: Cabaran dan Harapan,' (Paper presented at the Seminar Peletakhakan Tanah Wakaf: Cabaran dan Harapan 2012, Permaisuri Resort Port Dickson, Negeri Sembilan, 2012).

22 Nik Mohd Zain Mohd Yusof \& Azimuddin Bahari, 'Kedudukan dan Potensi Pembangunan Hartanah Wakaf di Malaysia: Satu Penilaian,' 106-154.

23 Abdul Halim Ramli \& Kamarulzaman Sulaiman, 'Pembangunan Harta Wakaf: Pengalaman Negara-Negara Islam.'

24 Fahmi Medias, 'Wakaf Produktif dalam Perspektif Ekonomi Islam,' Jurnal Ekonomi Islam (La Riba) IV (1) (2010): 69-84. 
is one that enables the socio-economic development of people, such as cash waqf, stock waqf, and waqf corporations. ${ }^{25}$

Therefore, some researchers have suggested that waqf should be promoted in order to create awareness about its importance as an economic driver as well as clarifiy its function and various manifestations. Among them are Yahya, in which he proposes a campaign to encourage people to keep donating their land or property as an aspect of religious duty. ${ }^{26}$ Zain and Azimuddin also suggests that knowledge of waqf should be nurtured in the education system, starting as early as possible, as the limitations of existing perceptions regarding waqf will lead to the undeveloped role of waqf institutions in the future. As such, a deep awareness of the importance of protecting and maintaining the practice of waqf both need to be instilled to develop waqf institutions. ${ }^{27}$ In addition, Latif et al. also state that awareness regarding the various forms of waqf, such as cash waqf, stock waqf, and waqf corporations is necessary for economic development and must be continued to encourage community participation in the development of waqf in Malaysia, whether directly or indirectly, in order to become the third sector as a complement to the government's development program. $^{28}$

\section{RESEARCH METHODOLOGY}

This research was conducted in the form of qualitative research. The methods of data collection used in this research were interviews and documentation. Interviews were conducted with seven officers of the Waqf Section of the MAINs, due to their experience and observations in the performance of duties as representatives of MAINs, which are the waqf trustees in their respective states. This study was conducted in selected states that were involved in

25 โซ๊ะ, บ. ห. ร. ด. น. บ. ย., 'The Concept of Wakaf, Reality Implementation in Patani,' Al-Hikmah, 3/6 (2013): 95-107.

26 Mohd Yusof Yahya, 'Pengurusan Wakaf di Perak: Amalan dan Perancangan,' in Konsep dan Pelaksanaan Wakaf di Malaysia, ed. Nik Hassan, N. M. (Kuala Lumpur: Institut Kefahaman Islam Malaysia (IKIM), 1999), 106-154.

27 Nik Mohd Zain Mohd Yusof \& Azimuddin Bahari, 'Kedudukan dan Potensi Pembangunan Hartanah Wakaf di Malaysia: Satu Penilaian,' 106-154.

28 Ahmad Zaki Abd Latiff, 'Pengurusan Harta Wakaf di Malaysia: Realiti \& Prospek'; Nurul Asykin Mahmood \& Muhammad Hakimi Mohd Shafiai, 'Potensi Wakaf Korporat Kepada Pemilikan Ekuiti Muslim: Kajian di Wakaf An-Nur Corporation,' (Paper presented at the Persidangan Kebangsaan Ekonomi Malaysia ke VIII (PERKEM VIII), Johor Bahru, Jun 2013). 
developing the waqf project with YWM: Kelantan, Selangor, Negeri Sembilan, Malacca, Johor, and Federal Territories.

The selection of Selangor Waqf Corporation (PWS) and Majlis Agama Islam Johor (MAIJ) was due to their high collection of cash waqf stocks, and also because of the more active waqf campaign they engaged in through the media. In addition, the selection of the Islamic Religious Council of Federal Territory (MAIWP) and the Negeri Sembilan Waqf Corporation (PWNS) as subjects of study are because both have made efforts to introduce and reinforce the understanding of cash waqf to the public. Meanwhile, the selection of Majlis Agama Islam Negeri Kelantan (MAIK) is due to Kelantan being among the larger Muslim population in Malaysia, after Johor and Kedah. ${ }^{29}$

Interview questions were sent in advance to the respondents. Each interview took between one hour and one hour and a half. All of the interviews were then recorded and analyzed according to a thematic analysis.

\section{ISSUES AND CHALLENGES OF COMMUNITY INVOLVEMENT IN MALAYSIA}

Based on these studies, there are some issues and challenges that the MAINs face in encouraging the Malaysian community to get involved in waqf. Among the issues and challenges is the confusion between waqf and donations, the tendency to contribute to specific waqf compared to general waqf, and also the tendency to endow in the form of immovable property compared to movable property. However, the public acceptance of waqf in the form of cash is also healthy and encouraging. In addition, the issues and challenges that need to be addressed by the MAINs are to clarify and introduce the waqf institutions to the public, as there are still many that do not know or recognize that waqf institutions distribute donations. Issues and challenges are further described below:

\section{Confusion in Differentiating between Waqf and Donations}

For the Waqf Division of the MAIWP, which is responsible for managing waqf in the Federal Territory, the religious council officers have found that most people are still somewhat confused about the differences between waqf and

29 Department of Statistics, Malaysia, 'Population Distribution and Basic Demographic Characteristic Report 2010,' https://www.statistics.gov.my/index. $\mathrm{php}$ ? $\mathrm{r}=$ column/cthemeByCat\&cat $=117 \&$ bul_id $=$ MDMxdHZjWTk1SjFzTzN kRXYzcVZjdz09\&menu_id=L0pheU43NWJ'wRWVSZklWdzQ4TlhUUT09, accessed 1 January 2016. 
donations. This is in contrast to people who have attended academic lecture and lectures in mosques; they tend to better understand and know the difference between waqf and donations. However, people within the Federal Territory are still mostly unfamiliar with the concept and the importance of waqf and are more accustomed to the practice of donations. ${ }^{30}$

\section{Prioritize the Specific Waqf Compared to General Waqf}

The experience of the Waqf Division, Islamic Religious Council, and Malay Custom of Kelantan, is that there is an awareness about waqf among people in Kelantan. However, people are more interested in the specific waqf compared to general waqf based on a sharp contrast with the number of collection records. The Kelantanese are also more likely to be involved in waqf for the purpose of building mosques or Muslim cemeteries. ${ }^{31}$

\section{Acceptance of Cash Waqf}

Acceptance in Malaysian society of cash waqf, whether in the form of waqf shares or waqf funds, is very promising. For example, in Kelantan, the total collection of cash waqf organized by the Waqf Foundation Malaysia in the Raudah Carnival received an overwhelming response from the community in Kelantan. Thus, the Waqf Division of MAIK believes that society's willingness to accept new types of waqf, namely cash waqf, is good. However, the understanding of waqf should be increased in order to focus more on general waqf and for MAIK to develop the existing waqf. This is because prior, society was more likely to give to specific waqf. ${ }^{32}$

As for the State of Selangor, the Selangor Waqf Corporation (PWS) and the Islamic Religious Council of Selangor (MAIS) are responsible for managing the development of waqf property. At the beginning of the establishment of the

30 Mohd Azrul Ismail (Assistance Manager of Zakat, Waqf, Wasiat and General Resources Management Unit, Majlis Agama Islam Wilayah Persekutuan (MAIWP)), in interview with author on 28 January 2014.

31 Shakirah Mohamad (Assistance Manager, Baitulmal Unit, Majlis Agama Islam dan Adat Istiadat Melayu Kelantan (MAIK) or Islamic Religious Affairs Council of Kelantan), in interview with author on 27 October 2013.

32 Shakirah Mohamad (Assistance Manager, Baitulmal Unit, Majlis Agama Islam dan Adat Istiadat Melayu Kelantan (MAIK) or Islamic Religious Affairs Council of Kelantan), in interview with author on 27 October 2013. 
Selangor Waqf Corporation, the campaign and program about awareness and understanding of waqf for society intensified and became the main mission.

Subsequently, the corporation found that after it was established for one year, public awareness and understanding increased based on the increase in the total collection of waqf, especially waqf shares. This was also driven by the Collection Division which was active in making collections. ${ }^{33}$ As a result, PWS managed to collect RM 993.342 for Selangor Waqf Shares in 2011 and this increased $300 \%$ in 2012 to a total of RM 4,004,452. In addition, the amount of Selangor Waqf Stock (Special) collection was RM 1,734,450.50 in 2011 and RM 7,648,764 for the year 2012. ${ }^{34}$

\section{The Tendency for Endowing the Immovable Waqf Type}

Meanwhile in Negeri Sembilan, the Negeri Sembilan Waqf Corporation (PWNS) so far has found that awareness and understanding of waqf is limited to immovable property. Due to this, the Corporation has emphasized an awareness and understanding campaign in the early stages, starting this year. ${ }^{35}$ Similarly, in Malacca, the Awqaf Division of the Islamic Religious Council of Malacca found that public awareness and understanding about waqf is still limited to immovable property. ${ }^{36}$

\section{Lack of Knowledge about the Institutions involved in Waqf Donations}

According to the experience of the Awqaf Division of the Islamic Religious Council of Johor (MAIJ), people have a basic awareness and understanding of waqf. This is based on the existence of waqf contributions in each talk, lecture, or tazkirah; even the contribution amount was substantial. However, Malaysian Muslims still lack knowledge and cannot recognize the institutions involved in waqf donations. Furthermore, the community has grown wary of giving

33 Mohd Huzairi Hamdan (Assistant Executive of Assessment, Selangor Waqf Corporation (PWS)), in interview with author on 5 November 2013; Shahrul Ashraf Jamaludin (Assistant Executive of Marketing, Selangor Waqf Corporation (PWS)), in interview with author on 25 November 2013.

34 Buletin Perbadanan Wakaf Selangor, bil. 1/2013, ISSN: 2289-2877, 4

35 Ali Mazri Mauludin (Executive, Negeri Sembilan Waqf Corporation (Perbadanan Wakaf Negeri Sembilan)), in interview with author on 4 February 2014.

36 Mohd Khabir Abdul Karim (Assistant, Department of Waqf and General Resources, Majlis Agama Islam Melaka (MAIM)), in interview with author on 4 February 2014. 
donations, including waqf, to an arbitrary person due to press releases and news reports about the irregularities of charity funds and donations. Therefore, MAIJ has taken some steps to describe the services offered including the collection of Johor waqf shares that will be distributed to eligible recipients. ${ }^{37}$

\section{EFFORTS TO INCREASE AWARENESS AND UNDERSTANDING OF $W A Q F$}

A number of activities have been planned and implemented by some MAINs in a committed and continuous way in order to intensify and expand the practice of waqf. These are discussed in detail below:

\section{Multiply Awareness Programs and Waqf Promotions}

In Selangor, PWS launched and implemented a number of activities and programs to disseminate the importance of waqf in society through sermons and religious lectures in every mosque in Selangor. Moreover PWS launched a number of monthly special programs such as 'Waqf Month', which is in the months of Rajab, Sha 'ban, and Ramadān, and 'The Month of Waqf with Women' to promote waqf gold. ${ }^{38}$ PWS also launched the BUMI Program (Industry-friendly Month) for waqf campaigning focused on the private sector. ${ }^{39}$

While in Johor, the MAIJ also committed itself to promoting waqf and its development. Along with lectures and information programs conducted in mosques, MAIJ conducted informational programs at universities. MAIJ has also used electronic media to spread information about waqf activities carried out in the community. ${ }^{40}$

37 Mustafayuddin Abd Halim (Assistance Director, Awqaf Division, Majlis Agama Islam Negeri Johor (MAIJ)), in interview with author on 7 November 2013.

38 PWS has seen great potential in promoting waqf for women since, nearly $80 \%$ waqif (endower) are women. Thus PWS has launched "Waqf of Gold" and "Month of Women Waqf". Before launching the former, PWS has received contributions in the form of gold for waqf of RM 27,000. Refer Utusan Malaysia Mobile (2013), m.utusan.com.my/Bicara_Agama/20130412/ba_02/PWS-perluas-konsep-wakaf, accessed 20 March 2014.

39 Mohd Huzairi Hamdan (Assistant Executive of Assessment, Selangor Waqf Corporation (PWS)), in interview with author on 5 November 2013; Shahrul Ashraf Jamaludin (Assistant Executive of Marketing, Selangor Waqf Corporation (PWS)), in interview with author on 25 November 2013.

40 Mustafayuddin Abd Halim (Assistance Director, Awqaf Division, Majlis Agama Islam Negeri Johor (MAIJ)), in interview with author on 7 November 2013. 
As for the MAIWP, dissemination of waqf practices among the people in the Federal Territory was planned and implemented in 2014. This was due to the lack of exposure related to waqf causes which has meant that some people are still confused about the difference between waqf and donations. Thus, the Religious Council has sought to emphasize and highlight the importance of waqf in each program it has organized, whether in a staff program or an external program. MAIWP also conducted a series of talks to launch the "Regional Waqf Month" in May 2014. ${ }^{41}$ In Negeri Sembilan, PWNS also tried to improve the promotion and information programs related to waqf more aggressively in order to encourage the community to participate in waqf practices, including expanding the medium of waqf through payroll deductions. ${ }^{42}$

\section{Launch An Awareness Program and Waqf Campaigns Among Staff First}

In order to spread waqf more effectively the MAIWP has tried to spread awareness and promote waqf to Religious Council staff first. The aim was to spread this practice through staff to their families, and from there to society as a whole. This began in February 2014. To encourage employees of MAIWP to get involved, payroll deductions have been implemented with a minimum rate of $\mathrm{RM} 1 .{ }^{43}$

\section{Publicize Waqf through Media}

MAIJ has launched a waqf promotional campaign through mass media such as the radio station of the Institut Kefahaman Islam Malaysia (IKIM), ikim. fm. MAIJ has found that the effects of radio advertising have stimulated public donations to the MAIJ waqf collection. Even people from other states besides Johor have become interested in participating in Johor Waqf Shares implemented by MAIJ. This is because the radio station, ikim.fm, covers the whole of Malaysia. ${ }^{44}$ In addition to MAIJ, the MAIWP is also using the same approach by publicizing waqf through mass media, such as radio and

41 Mohd Azrul Ismail (Assisstance Manager of Zakat, Waqf, Wasiat and General Resources Management Unit, Majlis Agama Islam Wilayah Persekutuan (MAIWP)), in interview with author on 28 January 2014.

42 Ali Mazri Mauludin (Executive, Negeri Sembilan Waqf Corporation (Perbadanan Wakaf Negeri Sembilan)), in interview with author on 4 February 2014.

43 Mohd Azrul Ismail (Assisstance Manager of Zakat, Waqf, Wasiat and General Resources Management Unit, Majlis Agama Islam Wilayah Persekutuan (MAIWP)), in interview with author on 28 January 2014.

44 Mustafayuddin Abd Halim (Assistance Director, Awqaf Division, Majlis Agama Islam Negeri Johor (MAIJ)), in interview with author on 7 November 2013. 
television. ${ }^{45}$ Besides radio advertising, MAIJ has also actively promoted waqf activities through electronic media, which is through the MAIJ website, e-wakaf and social media, such as Facebook and Twitter. It shouldn't be surprising that MAIJ is passionate and committed about spreading the waqf practice in the state of Johor. ${ }^{46}$

\section{Diversify the Waqf Products}

Some MAINs have diversified their waqf products by introducing and launching several contemporary waqf assets, including cash waqf and waqf shares. Previously, only land or buildings were given as waqf assets due to classical fatwa that waqf should be donated using immovable assets. The main goal of introducing cash waqf and waqf shares is to attract members of society to participate in giving waqf as anybody can donate money to a waqf fund even if they have only a little money based on their understanding - as long as their act is to seek Allah's pleasure.

Cash waqf will increase the funds to develop the existing waqf properties, as well as allow development projects to be run for the benefit of society. Furthermore, giving waqf through cash is easier than doing so through other properties, such as land and buildings, which are quite difficult to own because of their high value.

Moreover, most of the cash waqf schemes managed by the MAINs do not specify a minimum or maximum limit for each contribution. Thus, the contributor can give waqf according to their respective capabilities and this opens up more opportunities for all levels of society to get involved. Among the MAINs which have implemented the cash waqf and waqf shares are PWS with the Selangor Waqf Share Scheme; MAIJ with the Johor Waqf Share; MAINPP with the Penang Waqf Fund Scheme; the Islamic Religious Council and Malay Customs of Terengganu (MAIDAM) with the Terengganu Cash Waqf Scheme; the Islamic Religious Council and Malay Customs of Pahang (MUIP) with the

45 Mohd Azrul Ismail (Assisstance Manager of Zakat, Waqf, Wasiat and General Resources Management Unit, Majlis Agama Islam Wilayah Persekutuan (MAIWP)), in interview with author on 28 January 2014.

46 Mustafayuddin Abd Halim (Assistance Director, Awqaf Division, Majlis Agama Islam Negeri Johor (MAIJ)), in interview with author on 7 November 2013. 
Pahang Waqf Share (SWP) and PWNS with the Negeri Sembilan Cash Waqf Scheme. ${ }^{47}$

Other than cash waqf and waqf shares, PWS has also launched the arts waqf which donates some royalties from works of art, such as songwriting royalties and books. The arts waqf was launched in June 2013. PWS also launched a special waqf for women - the gold waqf - as normally women own jewelry through wedding gifts or inheritance from their mothers and grandmothers. ${ }^{48}$

\section{Diversify the Medium for Waqf}

In order to complete the waqf ceremony, donors fill in the entry form that contains the waqf deed or sighah to appoint the MAIN as a representative for their waqf property. Hence, to facilitate people to contribute, the MAIN has diversified the mediums for waqf, including contributions over the counter in the MAIN office, mobile counters, postal, checks, on-line transactions, and through salary deduction schemes. All of these options have been provided to facilitate and encourage the participation of society in waqf. Most MAINs, such as MAIJ, MAINPP, and PWS (Infaq Scheme) ${ }^{49}$ have been implementing waqf through salary deduction schemes because these methods help waqif to do waqf continuously with only one approval of the transaction for the amount allocated by contributors. ${ }^{50}$ PWNS and MAIWP also have plans to add this

47 Farhana Mohamad Suhaimi \& Asmak Ab Rahman, 'Perkembangan Wakaf Tunai dan Potensi Sumbangannya dalam Pembangunan Sosioekonomi Masyarakat Islam,' (Paper presented at the International Seminar on Research in Islamic Studies II (ISRIS II), Universiti Malaya, Kuala Lumpur, 2012).

48 Mohd Huzairi Hamdan (Assistant Executive of Assessment, Selangor Waqf Corporation (PWS)), in interview with author on 5 November 2013; Shahrul Ashraf Jamaludin (Assistant Executive of Marketing, Selangor Waqf Corporation (PWS)), in interview with author on 25 November 2013.

49 Mohd Huzairi Hamdan (Assistant Executive of Assessment, Selangor Waqf Corporation (PWS)), in interview with author on 5 November 2013; Shahrul Ashraf Jamaludin (Assistant Executive of Marketing, Selangor Waqf Corporation (PWS)), in interview with author on 25 November 2013.

50 Farhana Mohamad Suhaimi \& Asmak Ab Rahman, 'Perkembangan Wakaf Tunai dan Potensi Sumbangannya dalam Pembangunan Sosioekonomi Masyarakat Islam.' 
kind of waqf medium so that the practice can be performed more easily and effectively. ${ }^{51}$

\section{Establish A Smart Partnership}

In order to develop waqf properties in Selangor, PWS has also forged a smart partnership through cooperation with Bank Muamalat Malaysia Berhad (BMMB). This collaboration was intended to manage the waqf fund jointly through the establishment of a Joint Management Committee (JPB) between the bank and PWS. BMMB was the first banking institution to run a joint management of waqf funds in partnership. The formation of Waqf SelangorMuamalat focusses on education and health. The Health Waqf includes the development of health infrastructure, equipment financing, healthcare costs, and health research funds. While the Education Waqf includes the development of education infrastructure, equipment financing, fees funding. or scholarships and research funds for education. In addition, funds are also generated through permitted investments. $^{52}$

In order to spread the waqf culture among the community in Malaysia generally, and particularly in Selangor, a smart partnership with the media has also been created. PWS has worked with Karangkraf as media partners to achieve this goal. Besides that, PWS has also cooperated with the private sector, government, and schools for the purpose of promoting and informing about waqf around Selangor. ${ }^{53}$

51 Ali Mazri Mauludin (Executive, Negeri Sembilan Waqf Corporation (Perbadanan Wakaf Negeri Sembilan)), in interview with author on 4 February 2014.; Mohd Azrul Ismail (Assisstance Manager of Zakat, Waqf, Wasiat and General Resources Management Unit, Majlis Agama Islam Wilayah Persekutuan (MAIWP)), in interview with author on 28 January 2014.

52 Mohd Huzairi Hamdan (Assistant Executive of Assessment, Selangor Waqf Corporation (PWS)), in interview with author on 5 November 2013; Shahrul Ashraf Jamaludin (Assistant Executive of Marketing, Selangor Waqf Corporation (PWS)), in interview with author on 25 November 2013.; Bank Muamalat Malaysia Berhad (BMMB), http://www.muamalat.com.my/consumer-banking/ other-services/wakaf-selangor/overview.html, accessed 10 November 2013.

53 Mohd Huzairi Hamdan (Assistant Executive of Assessment, Selangor Waqf Corporation (PWS)), in interview with author on 5 November 2013; Shahrul Ashraf Jamaludin (Assistant Executive of Marketing, Selangor Waqf Corporation (PWS)), in interview with author on 25 November 2013. 


\section{Monitoring by the National Audit Department}

All funds raised and managed by the MAIJ are monitored by the National Audit Department and several other parties. This monitoring is essential to ensure that the funds raised are well managed and transparent. In fact, MAIJ believes that the monitoring carried out through an audit of the various parties is favorable to MAIJ because it will gain public confidence as well as encourage the community to participate in waqf through MAIJ. Consequently, the online system may be backed up due to many people who want to do waqf, especially during Ramadan and December $31^{\text {st }}$ of each year. ${ }^{54}$

Overall, the approach of MAINs in disseminating waqf in Malaysia, despite their differences, shows their sincerity towards the project. This effort must be continuous and enhanced in parallel with the current situation. This is because today technology has become a necessity for convenience and time constraints. Thus, the approach through current technological facilities, such as mobile applications, social media, or websites can promote waqf as well as publicize the activities and programs conducted. Strategic alliances with governments, the private sector, and universities involved in the development of waqf can reduce the costs of developing these applications as well. Through applications on mobile phones, social media, and websites, the functions and roles of waqf projects can be delivered to users as well as the latest information about waqf property development. This can build the confidence and trust of users to perform waqf on a continuous basis.

\section{CONCLUSION}

The results show there to be a significant pattern between the types of public awareness in each state and efforts (types of interventions and programmes that have been conducted) of the MAINs in their respective states. Firstly, people in Johor, Kelantan, Selangor, Negeri Sembilan, and Malacca have a general awareness about waqf. While in the Federal Territory, MAIWP has found that some people in the area are still somewhat confused about the differences between waqf and donations. This happens due to less programs or campaigns regarding waqf compared to zakah conducted by MAIWP in the Federal Territory. Secondly, MAINs gave less exposure to the public regarding the latest waqf products, since some of them have legal constraints such as in Kelantan, Negeri Sembilan, and Malacca. This causes their communities to

54 Mustafayuddin Abd Halim (Assistance Director, Awqaf Division, Majlis Agama Islam Negeri Johor (MAIJ)), in interview with author on 7 November 2013. 
be more interested to give waqf in the form of immovable property and favor a specific waqf. Thus, the MAINs have put in place numerous measures to intensify and expand this practice. Among the plans are to multiply awareness programs and waqf promotions; launch an awareness program and waqf campaign among staff first; publicize waqf practices through the media; diversify the medium for waqf; diversify waqf products; and create a smart partnership with the private sector and government.

However, all of MAINs have found that the understanding of waqf still needs to be improved in order to encourage public participation in waqf development - directly or otherwise - and maintain waqf as the third sector and one that complements the government's development program. Therefore, the waqf sector can act accordingly to help ease the burden of government spending and services to meet the needs of Malaysians. The efforts to increase public awareness and understanding related to waqf should be diversified with an effective approach so the role of waqf can be optimized as an instrument of public funding.

\section{REFERENCES}

Abdul Halim Ramli, \& Kamarulzaman Sulaiman, 'Pembangunan Harta Wakaf: Pengalaman Negara-Negara Islam,' (Paper presented in Konvensyen Wakaf Kebangsaan, Kuala Lumpur, 12-14 September 2006).

Ahmad Zaki Abd Latiff, 'Pengurusan Harta Wakaf di Malaysia: Realiti \& Prospek,' (Paper presented in Islamic Real Estate Education: A New Paradigm, UiTM Shah Alam, Selangor, November 2011).

Ahmad Zaki Ibrahim, 'Institusi al-Azhar: Keunggulan Pengurusan Dana Wakaf dalam Sejarah Tamadun Islam,' (Paper presented in Waqf Seminar, Seminar Wakaf Melestarikan Hadharah Ummah, Putrajaya, 22 December 2009).

Anan C. Mohd, 'Pembangunan Tanah Wakaf: Cabaran dan Harapan,' (Paper presented at the Seminar Peletakhakan Tanah Wakaf: Cabaran dan Harapan 2012, Permaisuri Resort Port Dickson, Negeri Sembilan, 2012).

Al-Baijūrī, Ibrāhīm, Hāshiyah al-Sheīkh Ibrāhīm al-Baijūrī; Sharh 'Alā Matan al-Sheīkh Abì Shujā', vol. 2 (Beirūt: Dār al-Kutub al-'Ilmiyyah, 2004).

Bank Muamalat Malaysia Berhad (BMMB), 'Wakaf Selangor Muamalat,' http://www.muamalat.com.my/consumer-banking/other-services/ wakaf-selangor/overview.html, accessed 10 November 2013.

Perbadanan Wakaf Selangor, Buletin Perbadanan Wakaf Selangor, vol. 1 (Shah Alam: PWS, 2013). 
Fahmi Medias, 'Wakaf Produktif dalam Perspektif Ekonomi Islam,' Jurnal Ekonomi Islam (La Riba) IV (1) (2010): 69-84.

Farhana Mohamad Suhaimi \& Asmak Ab Rahman, 'Perkembangan Wakaf Tunai dan Potensi Sumbangannya dalam Pembangunan Sosioekonomi Masyarakat Islam,' (Paper presented at the International Seminar on Research in Islamic Studies II (ISRIS II), Universiti Malaya, Kuala Lumpur, 2012).

Ibn Kathīr, Tafsīr Ibn Kathīr, vol. 1 (Mișr: Maktabah Zahrān, n.d.).

Al-Khațīb al-Sharbīnī, al-Iqnā' fì Hil al-Alfāz Abì Shujā', vol. 2 (Beirūt: Dār al-Kutub al-'Ilmiyyah, 2004).

Al-Khațīb al-Sharbīn̄̄, Mughnī al-Muhtāj Ilā Ma 'rifah Ma 'ānī Alfāza al-Minhāj al-Ṭālibìn, vol. 2 (Beirūt: Dār al-Fikr, 1978).

Mālik bin Anas, al-Mūwațta ' (Beirūt: Bayt al-Afkār al-Dawliyyah, 2004).

Mohammad Nejatullah Siddiqi, Role of the State in the Economy an Islamic Perspective (Leicester, United Kingdom: The Islamic Foundation, 1996).

Mohd Yusof Yahya, 'Pengurusan Wakaf di Perak: Amalan dan Perancangan,' in Konsep dan Pelaksanaan Wakaf di Malaysia, ed. Nik Hassan, N. M. (Kuala Lumpur: Institut Kefahaman Islam Malaysia (IKIM), 1999), 106-154.

Monzer Kahf, 'Waqf and its Sociopolitical Aspects', www.iefpedia.com/ english/wp.../Waqf-and-its-Socio-Political-Aspects1.pdf, accessed 20 March 2014.

Monzer Kahf, 'Waqf: A Quick Review', http://monzer.kahf.com/papers/ english/WAQF_A_QUICK_OVERVIEW.pdf, accessed 20 March 2014.

Muhammad Taqi-ud-Din Al-Hilali \& Muhammad Muhsin Khan, Translation of the Meanings of the Noble Qur'an in the English Language (Madinah: King Fahd Complex for the Printing of the Holy Qur'an, 2000).

Nik Mohd Zain Mohd Yusof \& Azimuddin Bahari, 'Kedudukan dan Potensi Pembangunan Hartanah Wakaf di Malaysia: Satu Penilaian,' in Konsep dan Pelaksanaan Wakaf di Malaysia, ed. Nik Hassan, N. M. (Kuala Lumpur: Institut Kefahaman Islam Malaysia (IKIM), 1999), 106-154.

Nik Mustapha Nik Hassan, 'Program Wakaf Proaktif Galak Penyertaan Umat,' http://e-kiosk.ikim.gov.my/downloadarticle.asp?id=53, accessed 1 September 2013.

Nik Mustapha Nik Hassan, 'Sumbangan Institusi Wakaf kepada Pembangunan Ekonomi,' in Konsep dan Pelaksanaan Wakaf di Malaysia, ed. Nik Mustapha Nik Hassan (Kuala Lumpur: Institut Kefahaman Islam Malaysia (IKIM), 1999), 1-16. 
Nurul Asykin Mahmood \& Muhammad Hakimi Mohd Shafiai, 'Potensi Wakaf Korporat Kepada Pemilikan Ekuiti Muslim: Kajian di Wakaf An-Nur Corporation,' (Paper presented at the Persidangan Kebangsaan Ekonomi Malaysia ke VIII (PERKEM VIII), Johor Bahru, Jun 2013).

Al-Qurțub̄̄, al-Jāmi ' li Ahkā̄m al-Qur’ān, vol. 2 (Beirūt: Dār al-Kutub al'Ilmiyyah, 1993).

Shams al-Dīn Muḥammad, Nihāyah al-Muhtāj Ilā Sharh al-Minhāj, vol. 5 (Miṣr: Maktabah Mușțafa al-Bābī al-Halābīi, 1938).

Siti Mashitoh Mahamood et al., 'Konsep dan Aplikasi Produk Wakaf Kontemporari di Malaysia: Saham Wakaf dan Wakaf Saham,' (Paper presented at the Seminar Ekonomi Islam Peringkat Kebangsaan 2009 (SEIPK '09), University of Malaya, Kuala Lumpur, 2009).

Siti Mashitoh Mahamood, 'Undang-Undang Pentadbiran Harta Wakaf,' (Paper presented at Seminar Penyelidikan Jangka Pendek (Vote F), University of Malaya, Kuala Lumpur, 11-12 Mac 2003).

Utusan Malaysia Mobile, 'PWS perluas konsep wakaf,' m.utusan.com.my/ Bicara_Agama/20130412/ba_02/PWS-perluas-konsep-wakaf, accessed $20 \mathrm{Mac} 2014$.

Utusan Online Arkib, 'Aktifkan Peranan Sektor Ketiga,' http:/www.utusan. com.my/utusan/ekonomi/20120611/ek_01/aktifkan-peranan-sektorketiga\#ixzz2DaEO78IQ, accessed 29 November 2012.

Yayasan Waqaf Malaysia, 'Visi dan Misi,' https://www.ywm.gov.my/profile/ visi, accessed 20 March 2014.

Ziauddin Ahmad, 'Public Finance in Islam,' IMF Working Paper, No.89/68, (1989): 1-54.

โซ๊ะ, บ. ห. ร. ด. น. บ. ย., 'The Concept of Wakaf, Reality Implementation in Patani,' Al-Hikmah, 3/6 (2013): 95-107.

\section{Statute}

Federal Constitution.

\section{Interviews}

Ali Mazri Mauludin (Executive, Negeri Sembilan Waqf Corporation (Perbadanan Wakaf Negeri Sembilan)), in interview with author on 4 February 2014. 
Mohd Azrul Ismail (Assisstance Manager of Zakat, Waqf, Wasiat and General Resources Management Unit, Majlis Agama Islam Wilayah Persekutuan (MAIWP)), in interview with author on 28 January 2014.

Mohd Huzairi Hamdan (Assistant Executive of Assessment, Selangor Waqf Corporation (PWS)), in interview with author on 5 November 2013.

Mohd Khabir Abdul Karim (Assistant, Department of Waqf and General Resources, Majlis Agama Islam Melaka (MAIM)), in interview with author on 4 February 2014.

Mustafayuddin Abd Halim (Assistance Director, Awqaf Division, Majlis Agama Islam Negeri Johor (MAIJ)), in interview with author on 7 November 2013.

Shahrul Ashraf Jamaludin (Assistant Executive of Marketing, Selangor Waqf Corporation (PWS)), in interview with author on 25 November 2013.

Shakirah Mohamad (Assistance Manager, Baitulmal Unit, Majlis Agama Islam dan Adat Istiadat Melayu Kelantan (MAIK) or Islamic Religious Affairs Council of Kelantan), in interview with author on 27 October 2013. 